\title{
FOOD SAFETY MANAGEMENT SYSTEM DI HOTEL RESORT AREA KABUPATEN GARUT
}

\author{
R. Sondjana Ali Suganda ${ }^{1}$ \\ Sekolah Tinggi Pariwisata Bandung \\ cibunut@yahoo.com \\ R. Darmawan Sundayana ${ }^{2}$ \\ Sekolah Tinggi Pariwisata Bandung \\ darmawansundayana2@gmail.com \\ Hery Soesanto ${ }^{3}$ \\ Sekolah Tinggi Pariwisata Bandung \\ herykoesfans@gmail.com \\ R. Kusherdyana ${ }^{4}$ \\ Sekolah Tinggi Pariwisata Bandung \\ kusherdyana@gmail.com \\ Syaeful Muslim ${ }^{5}$ \\ Sekolah Tinggi Pariwisata Bandung \\ sam@stp-bandung.ac.id
}

\begin{abstract}
The purpose of this study was to determine the procedure for receiving perishable raw materials at the Resort Hotel area of Garut Regency and understand the application of the Food Safety Management System on the receiving area for perishable raw materials at the Resort Hotel area of Garut Regency. The method used in this study is a qualitative method. The object of this research was carried out in a number of Resort Hotels in the Garut Regency area. The sampling technique in this study was carried out using purposive sampling method. The data collection technique was carried out by in-depth interviews with the receiving sections at each hotel in Garut district (Dariza Resort, Sumber Alam Resort, Kampung Sampireun Resort, Sabda Alam Resort). Direct observations were made on each receiving process at each hotel area in Garut district. The data collection tool was carried out by means of a checklist as well as an interview guide. The results showed that the receiving process in the hotel area of Garut Regency was quite good but there were still deficiencies in the application of the receiving process in terms of the procedure for receiving perishable food raw materials, delivery from suppliers to food raw material receiving officers did not have chiller or coolers and did not provide labeling. or food container stamp with the date it was received.
\end{abstract}

Keywords: Food Safety, Receiving Process, Hospitality, Garut District 


\begin{abstract}
ABSTRAK
Tujuan penelitian ini adalah untuk mengetahui prosedur receiving bahan baku perishable di Resort Hotel area Kabupaten Garut dan memahami Penerapan Food Safety Management System pada area receiving bahan baku perishable di Resort Hotel area Kabupaten Garut. Metode yang digunakan dalam penelitian ini yaitu metode kualitatif. Obyek penelitian ini dilakukan di sejumlah Hotel Resort daerah Kabupaten Garut. Teknik sampling dalam penelitian ini dilakukan dengan menggunakan metode purposive sampling. Teknik pengumpulan data dilakukan dengan wawancara secara mendalam kepada bagian receiving pada setiap hotel di kabupaten Garut (Dariza Resort, Sumber Alam Resort, Kampung Sampireun Resort, Sabda Alam Resort). Observasi secara langsung dilakukan pada setiap proses receiving yang ada di setiap hotel area Kabupaten Garut. Alat pengumpul data dilakukan dengan daftar checklist juga dengan pedoman wawancara. Hasil penelitian menunjukkan bahwa proses receiving di area hotel Kabupaten Garut sudah cukup baik namun masih terdapat kekurangan pada penerapan proses receiving dalam hal prosedur penerimaan bahan baku makanan perishable, pengiriman dari supplier kepada petugas penerima bahan baku makanan tidak memiliki chiller atau pendingin dan tidak melakukan pemberian label atau stempel wadah makanan dengan tanggal penerimaan.
\end{abstract}

Kata Kunci: Keamanan Pangan, Proses Penerimaan, Perhotelan, Kabupaten Garut

\title{
PENDAHULUAN
}

Industri perhotelan adalah suatu bidang industri yang bergerak dalam bidang jasa. Selain menyediakan fasilitas kamar, industri perhotelan juga menyediakan logistik makanan dan minuman. Selain menjual kamar hotel juga mendapat pemasukkan dari penjualan makanan dan minuman. Fungsi utama usaha perhotelan ialah untuk memberikan pelayanan kepada tamu berupa tempat tinggal, atau tempat menginap yang bersifat sementara. Wisatawan nusantara (wisnus) dan wisatawan mancanegara (wisman) memerlukan layanan akomodasi penginapan (hotel), konsumsi, transportasi, industri kreatif dan industri penunjang lain yang terkait maka usaha perhotelan dan mata rantai usaha lainnya akan semakin berkembang sejalan dengan pertumbuhan sektor pariwisata (Suwithi, 2013).

Restoran merupakan tempat menjual makanan dan minuman yang disajikan kepada konsumen atau tamu. Menurut Marsum (2005), restoran adalah suatu tempat atau bangunan yang diorganisir secara komersial, yang menyelenggarakan pelayanan dengan baik kepada semua tamunya baik berupa makanan maupun minuman. Agar pelanggan atau tamu dapat menikmati sajian makanan dan minuman yang disediakan restoran dengan baik dan aman, maka penting bagi restoran atau industri penyedia makanan dan minuman untuk memperhatikan kualitas produk makanan dan minuman yang akan disajikan.

Food safety management system adalah pencegahan, eliminasi dan pengendalian bahaya bawaan makanan, dari tempat produksi hingga titik konsumsi (Teixeira \& Sampaio, 2011). Menurut Koto (2012), food safety management system yang merupakan gabungan prinsip-prinsip sistem analisis bahaya dan pengendalian 
titik kritis serta langkah-langkah penerapan yang dikembangkan yang menjamin keamanan pangan sepanjang rantai pangan, dengan menjamin bahwa pangan yang akan diproses hingga dikirim kepada konsumen akhir adalah pangan yang bebas dari cemaran mikrobiologi, cemaran kimia, dan cemaran fisik. Penerapan dari food safety management system di seluruh dunia telah meningkat secara signifikan. Sedangkan menurut Rahayu (2011), food safety dapat diartikan sebagai kondisi dari upaya yang diperlukan untuk mencegah makanan dari kemungkinan pencemaran biologi, kimia, dan benda lain yang dapat mengganggu, merugikan, dan membahayakan kesehatan manusia. Manajemen sebagai suatu proses, melihat bagaimana cara orang untuk mencapai suatu tujuan yang telah ditetapkan terlebih dahulu selama beberapa tahun terakhir, sehingga mencerminkan pentingnya asumsi standar-standar ini di beberapa sektor kegiatan (Teixeira \& Sampaio, 2011). Perhatian utama seorang konsumen terletak dalam keamanan pangan, kualitas dan keaslian. Memiliki prosedur pengendalian makanan menjadi sangat penting di zaman sekarang ini, dimana wabah penyakit yang ditularkan melalui makanan sering terjadi. Prosedur seharusnya tidak hanya menekankan pada pemeliharaan makanan higienis dalam segala hal, harus cepat saji, dapat diandalkan dan hemat biaya (Marwaha, 2007).

Praktik keamanan pangan dapat dianggap sebagai aktivitas dan prosedur yang terlibat dalam memastikan makanan itu dikonsumsi tidak menyebabkan kerusakan tetapi mencapai tujuan yang diinginkan (Lagerkvist, et al., 2018). Sangat jelas terlihat gaya hidup modern didorong sebagian besar orang di kelas pekerja, terutama penghuni perkotaan, bergantung pada makanan di luar rumah. Orang bergantung pada industri perhotelan untuk sarapan, makan siang, makan malam, dan bahkan camilan larut malam (Alagiyawanna, 2018). Seperti turis, karena itu sama-sama rentan terhadap insiden keracunan makanan. Perlu dicatat bahwa dalam memasak skala besar seperti yang terbukti dalam industri perhotelan, makanan adalah dimanipulasi oleh banyak orang, yang meningkatkan masuk akal kontaminasi makanan (Akabanda, et al., 2017). Metode terbaik dan paling efektif menjamin keamanan pangan adalah dengan menetapkan sistematik dan pelatihan dan pendidikan berkelanjutan untuk penanganan makanan di perhotelan dan industri pengolahan makanan, pengelola perhotelan dan pengolahan makanan industri, pejabat pemerintah yang bertanggung jawab dengan keselamatan makanan serta konsumen. Dengan begitu, masalah keamanan pangan beserta bahaya dan risikonya dalam makanan bisa diminimalkan (Purnomo, 2006).

Penerapan Food Safety diterapkan oleh HAACP (Hazard Analysis and Critical Control Point). HACCP adalah alat internasional yang penerapannya dipergunakan di berbagai benua dan negara, seperti Uni Eropa, Amerika Serikat, Asia, Australia, Selandia Baru, dan Kanada. Pemerintah lain memiliki program sukarela untuk mempromosikan adopsi HACCP (Unnevehr \& Jensen, 1999). HACCP diakui sebagai pendekatan yang efektif dalam mengembangkan produksi yang memuaskan dan sanitasi serta praktik higienis tentang keamanan pangan, selain itu, HACCP saat ini dianggap sebagai prasyarat bagi produsen makanan sebelum diizinkan masuk pasar internasional (Arvanitoyannis \& Mavropoulos, 2000). Karenanya, HACCP membantu proses pengendalian dengan mengidentifikasi titik-titik operasi dalam proses produksi atau penanganan yang harus dipantau dan dikontrol secara kritis untuk memastikan keselamatan. HACCP 
dapat diterapkan pada setiap tahap atau jenis sistem pangan untuk tindakan korektif jika muncul masalah. Oleh karena itu, perusahaan makanan tertarik untuk menerapkan HACCP untuk pengendalian kualitas pangan. Berikut ini merupakan prosedur Food Safety yang akan menitikberatkan pada proses receiving dapat dilihat pada Gambar 1:

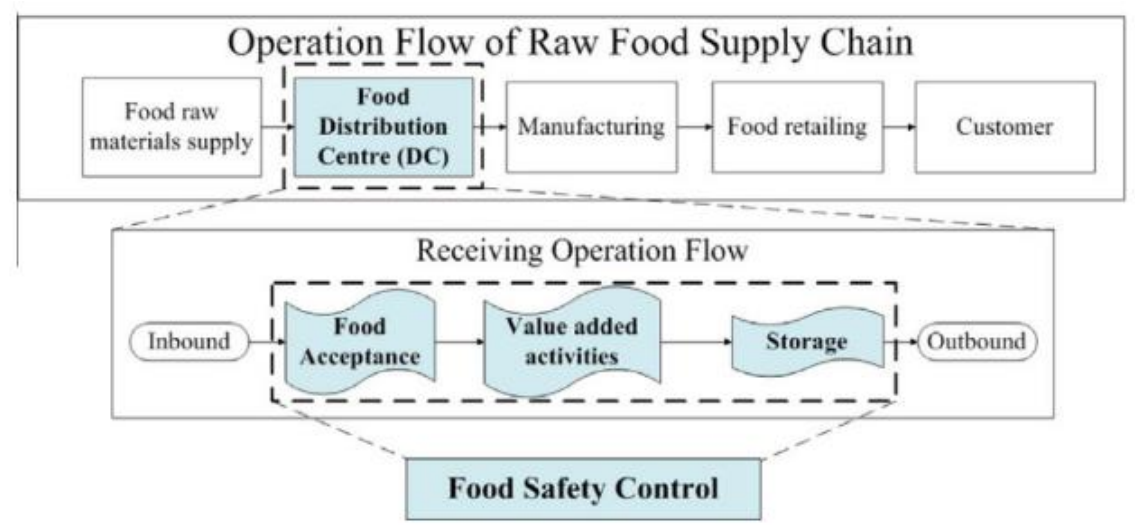

Gambar1. Operational Flow of Raw Food Supply Chain and Food Safety Control (Lao, et al., 2012)

Pada Gambar 1 di atas dapat disimpulkan bahwa rencana keamanan pangan terdiri dari potensi bahaya, titik kendali, titik kendali kritis, batas kendali, prosedur pemantauan, dan tindakan korektif (HKSAR, 2002). Dalam merumuskan elemenelemen ini, diperlukan serangkaian tindakan, seperti menganalisis potensi bahaya produk pangan, mengidentifikasi semua titik pemeriksaan operasi, mengidentifikasi titik pemeriksaan keamanan pangan kritis, dll. Secara tradisional, pengambil keputusan manusia dilibatkan dalam proses merumuskan keputusan tentang rencana keamanan pangan untuk persediaan yang akan datang. Saat produk masuk ke distribution centre, berbagai Standard Keeping Unit (SKU) ada pada produk. Pengambil keputusan diminta untuk memutuskan potensi bahaya saat ini. Untuk setiap potensi bahaya, titik kontrol yang berbeda harus diidentifikasi. Kemudian, batas kendali khusus ditentukan. Selanjutnya pengambil keputusan. Perlu membedakan titik kontrol kritis di antara kontrol poin. Terakhir, prosedur pemantauan dan tindakan korektif yang ditentukan harus diidentifikasi. Dengan pendekatan pengambilan keputusan pemantauan keselamatan proses, manajer distribution center menghadapi masalah sepanjang rencana implementasi keamanan pangan.

Menurut HAACP (2017), Food Safety Process (FSP) dirancang untuk mengidentifikasi dan mencegah kemungkinan masalah keamanan pangan (bahaya) untuk meningkatkan keamanan pangan. Masalahnya terkait dengan pembelian (buying), penerimaan (receiving), penyimpanan (storing), persiapan (preparation) , memasak (cooking), pengemasan (packaging), pengangkutan (transporting) atau tampilan makanan (food design). Ada enam elemen dalam FSP:

1. Masalah keamanan pangan (bahaya) pada setiap langkah pemrosesan makanan (misalnya pembelian dan penerimaan makanan)

2. Mengidentifikasi tindakan pencegahan dan batas kendali mereka

3. Tetapkan prosedur pemantauan

4. Tetapkan tindakan korektif 


\section{Menyimpan catatan \\ 6. Periksa dan ulas}

Penerapan yang tepat dari elemen di atas, bersama dengan penerapan beberapa praktik dasar (misalnya pembersihan dan sanitasi, kebersihan diri, pengendalian hama, pembuangan limbah, dan pelatihan staf), pasti akan mencegah masalah keamanan pangan selama produksi pangan.

Hal yang akan dibahas dalam penelitian ini dalam Food Safety Process adalah proses penerimaan atau receiving. Selama proses receiving, berbagai karakteristik SKU, seperti warna, tekstur, (storage periode) lama penyimpanan, (storage condition) kondisi penyimpanan, ketinggian air, kategori makanan perlu dipertimbangkan. Karenanya, dengan banyaknya parameter yang harus diperhatikan, dibutuhkan kerangka waktu yang lama dalam pengambilan keputusan (Lao, et al., 2012). Proses Food Safety pada proses receiving dan parameternya (HAACP, 2017) menyimpulkan bahwa bahan mentah atau bahan harus diperiksa dengan spesifikasi pada pengiriman. Bergantung pada tingkat risikonya, beberapa makanan atau bahan mentah perlu lebih sering diperiksa. Setelah proses receiving dilakukan, item makanan harus disimpan dengan baik sesuai dengan kondisi yang benar, suhu, dll. Penyimpanan didefinisikan oleh Foskett, et al. (2003), Cornelius dan Cronan, 1979) sebagai menyimpan persediaan di ruang penyimpanan, lemari es, freezer, atau lemari. Hoof, et al. (1996) menyebutkan bahwa setiap makanan memiliki standar penyimpanan. Mereka juga menyatakan bahwa penyimpanan dirancang untuk menjaga kualitas produk sekaligus mengurangi kerugian akibat pencurian dan pembusukan. Cornelius dan Cronan (1979) mendefinisikan produksi sebagai penyediaan setiap departemen dengan item yang mereka ambil, sedangkan Davis et al. (1999) mendefinisikan produksi pangan sebagai "pengolahan bahan makanan mentah, setengah jadi, atau siap saji. Ninemeier dan Perdue (2005) mendefinisikannya sebagai "proses menyiapkan produk untuk dikonsumsi. Berikut pemaparan prosedur checking list receiving pada safety food HAACP (2017):

1. Melatih karyawan jasa makanan dalam menggunakan prosedur Food Safety

2. Periksalah truk pengiriman saat tiba untuk memastikan bahwa truk tersebut bersih, bebas dari bau busuk, hama, dan terorganisir untuk mencegah kontaminasi silang. Pastikan makanan yang didinginkan dan dibekukan dikirim dengan truk yang sesuai.

3. Periksa suhu interior truk berpendingin dan freezer pada saat penerimaan bahan baku makanan sesuai berikut ini:

4. Suhu bahan mentah pada saat kedatangan: $4^{\circ} \mathrm{C}$ atau lebih rendah (makanan dingin) / beku seluruhnya (makanan beku)

5. Truk berpendingin untuk buah, daging dan sayur.

6. Konfirmasi nama vendor, hari dan waktu pengiriman, serta identifikasi pengemudi sebelum menerima pengiriman. Jika nama pengemudi berbeda dengan yang tertera pada jadwal pengiriman, segera hubungi vendornya.

7. Periksa makanan beku untuk memastikan bahwa semuanya beku dan tidak menunjukkan tanda-tanda mencair.

8. Periksa buah dan sayur untuk memastikan dalam keadaan baik dan bebas hama. 
9. Periksa suhu makanan yang didinginkan (daging segar, ikan, produk unggas), untuk produk kemasan, masukkan termometer makanan di antara dua kemasan dengan hati-hati agar pembungkusnya tidak bocor. Jika suhu melebihi $4{ }^{\circ} \mathrm{C}$, mungkin perlu mengukur suhu internal sebelum menerima produk. Dalam hal ini, probe termometer harus dibersihkan dengan kapas alkohol sebelum mengukur suhu.

10. Periksa tanggal barang yang mudah rusak untuk memastikan keamanan dan kualitas, dan bahwa produk tidak melewati tanggal terbaik sebelum tanggal kadaluarsa.

11. Periksa integritas kemasan makanan.

12. Periksa kebersihan tempat dan wadah pengiriman lainnya sebelum menerima produk. Tolak makanan yang dikirim dalam tempat kotor.

13. Memberi label atau stempel wadah makanan dengan tanggal penerimaan.

14. Menggunakan First-In-First-Out, pastikan bahwa produk yang baru diterima ditempatkan di belakang stok saat ini.

15. Melakukan corrective action apabila ada kesalahan atau kerusakan bahan baku makanan.

Menurut Puckett dan Ninemeier (1993) receiving berarti memeriksa makanan yang dikirim atau makanan dari vendor untuk: item yang benar, kuantitas tertentu, kualitas, kriteria keamanan pangan, dan menerima atau menolak makanan tergantung pada kriteria penerimaan. Juga, Robinson (2012) meyakinkan bahwa semua makanan harus berada dalam kondisi sangat baik saat mereka tiba. Kualitas dan suhu makanan harus dipantau dengan ketat saat pengiriman. Juga, waktu pengiriman untuk periode yang lambat harus direncanakan. Selain itu, Robinson (2012) menambahkan bahwa area penyimpanan harus dibersihkan terlebih dahulu sebelum menerima kiriman, sehingga makanan dapat segera disimpan. Area penyimpanan harus bersih dan cukup penerangan untuk mencegah hama. Menurut NSW Food Authority (2011), setelah makanan diterima, makanan harus ditempatkan di bawah penyimpanan berpendingin; jaga agar tetap panas, atau segera tampilkan dengan waktu yang direkam. Juga, periksa suhu makanan yang diterima yang harus di bawah $4^{\circ} \mathrm{C}$ atau di atas $60^{\circ} \mathrm{C}$; Akhirnya, suhu di luar kisaran ini harus dicatat dan makanan ditolak atau dilakukan penilaian untuk keamanannya. Menurut Guide to the Food Safety Standards (2001), bisnis makanan harus mengambil semua tindakan praktis untuk memastikan bahwa hanya menerima makanan yang dilindungi dari kemungkinan kontaminasi. Selain itu, bisnis makanan harus memberikan informasi berikut: nama dan alamat bisnis vendor, produsen atau pengemas atau nama dan alamat bisnis importir. Selain itu, diperlukan nama yang ditentukan atau sebutan makanan yang sesuai.

Penulis menemukan beberapa indikasi yang menunjukan adanya kelemahan pada FSMS, yaitu pada saat penerimaan bahan baku di Danau Dariza Resort, Sabda Alam Resort, Sumber Alam Resort dan Sampireun Resort. Hal ini terlihat saat proses unloading bahan baku yaitu salah satunya supplier tidak memiliki alat transportasi pendingin untuk proses pengiriman bahan baku yang mudah rusak (perishable product) hal ini apabila tidak ditangani dapat mengakibatkan adanya kontaminasi silang (cross contamination) pada setiap bahan baku makanan sehingga bahan baku makanan tidak segar dan akan mudah busuk. Observasi awal secara langsung dilakukan pada Danau Dariza Resort, Sabda Alam Resort, Sumber 
$$
\text { . }
$$

Alam Resort dan Sampireun Resort terhadap bagian bidang penerimaan bahan baku makanan, menyebutkan bahwa mutu bahan makanan perishable/ yang mudah rusak seperti daging kesegaran nya tidak konsisten dan adanya kesulitan penentuan bahan baku perishable yang dipesan dalam penerimaan jumlah besar. Penelitian mengenai keamanan pangan dan proses penerimaan bahan baku makanan ini penting dilakukan karena proses penerimaan adalah titik kontrol pertama dalam aliran makanan (food cycle). Jadi, ketelitian dalam proses penerimaan dapat mengurangi cacat atau kesalahan yang mungkin terjadi untuk masalah potensial di seluruh sistem (Shiring et al., 2001).

Penelitian terdahulu yang membahas mengenai FSMS berjudul "Implementation Of Food Safety Management System - Where It Brings The Real Value: A Case Study From Polish Enterprises" (Nowicki \& Dziadkowiec, 2016) membahas mengenai penerapan FSMS secara umum yang membawa nilai dan manfaat yang paling nyata. Temuan menunjukkan bahwa pengaruh terbesar penerapan FSMS menunjukkan bahwa karyawan lebih sadar akan kebersihan dan keamanan pangan, pengurangan risiko kesehatan dan penurunan produk pangan yang berpotensi berbahaya. Penelitian lainnya oleh Atia \& Abdelgawad (2017) yang berjudul "Receiving and Storing Foods: The Procedures Followed in the Central Restaurants at University Dormitories Receiving and Storing Foods: The Procedures Followed in the Central Restaurants at University Dormitories" membahas mengenai prosedur penerimaan dan penyimpanan makanan yang menitikberatkan pada pengaruh pelatihan yang diberikan kepada karyawan terhadap kedua prosedur tersebut. Hasil menunjukkan bahwa pelatihan tidak memiliki pengaruh yang kuat terhadap pengembangan karyawan untuk penerimaan dan penyimpanan makanan. Penelitian lain oleh Apriani \& Oda (2014) berjudul "Prosedur Pemesanan dan Penerimaan Bahan Pastry Untuk Kegiatan Produksi Di Hotel Hilton Bandung" yang membahas mengenai prosedur pemesanan dan penerimaan khusus pada bahan baku pastry yang menunjukkan bahwa prosedur pemesanan dan penerimaan pada bahan baku pastry belum terorganisir dengan baik. Dengan merujuk pada penelitian terdahulu, penelitian mengenai prosedur penerimaan bahan baku makanan perishable di Danau Dariza Resort, Sabda Alam Resort, Sumber Alam Resort dan Sampireun Resort ini memiliki indikasi masalah dalam proses penerimaan bahan baku makanan yaitu tidak adanya alat transportasi pendingin untuk proses pengiriman bahan baku yang mudah rusak (perishable product) dan pada penelitian-penelitian sebelumnya yang serupa dipaparkan pentingnya prosedur dari FSMS khususnya pada proses penerimaan bahan baku makanan sehingga masalah dari keempat hotel tersebut penting untuk ditangani.

Berdasarkan latar belakang tersebut di atas, penulis tertarik untuk mengetahui sejauh mana Food Safety Management System diterapkan di Resort Hotel di Danau Dariza, Sabda Alam, Sumber Alam dan Sampireun Kabupaten Garut, terutama pada proses penerimaan bahan baku (receiving). Oleh karena itu, penulis dalam penelitian ini mengangkat topik dan judul "Kajian Food Safety Management System Di Resort Hotel Area Kabupaten Garut". 


\section{METODOLOGI}

Penelitian ini menggunakan metode penelitian kualitatif. Menurut Raco (2018), secara umum metode penelitian didefinisikan sebagai suatu kegiatan ilmiah yang terencana, terstruktur, sistematis dan memiliki tujuan tertentu baik praktis maupun teoritis. Dikatakan sebagai kegiatan ilmiah karena penelitian dengan aspek ilmu pengetahuan dan teori. Teori yang digunakan dalam penelitian ini merujuk pada HAACP (2017) yang menyimpulkan bahwa bahan mentah atau bahan harus diperiksa dengan spesifikasi pada pengiriman. Berikut checklist receiving HAACP (2017) untuk memeriksa penerimaan bahan baku makanan:

1. Melatih karyawan jasa makanan dalam menggunakan prosedur Food Safety

2. Periksalah truk pengiriman saat tiba untuk memastikan bahwa truk tersebut bersih, bebas dari bau busuk, hama, dan terorganisir untuk mencegah kontaminasi silang. Pastikan makanan yang didinginkan dan dibekukan dikirim dengan truk yang sesuai.

3. Periksa suhu interior truk berpendingin dan freezer pada saat penerimaan bahan baku makanan sesuai berikut ini:

4. Suhu bahan mentah pada saat kedatangan: $4^{\circ} \mathrm{C}$ atau lebih rendah (makanan dingin) / beku seluruhnya (makanan beku)

5. Truk berpendingin untuk buah, daging dan sayur.

6. Konfirmasi nama vendor, hari dan waktu pengiriman, serta identifikasi pengemudi sebelum menerima pengiriman. Jika nama pengemudi berbeda dengan yang tertera pada jadwal pengiriman, segera hubungi vendornya.

7. Periksa makanan beku untuk memastikan bahwa semuanya beku dan tidak menunjukkan tanda-tanda mencair.

8. Periksa buah dan sayur untuk memastikan dalam keadaan baik dan bebas hama.

9. Periksa suhu makanan yang didinginkan (daging segar, ikan, produk unggas), untuk produk kemasan, masukkan termometer makanan di antara dua kemasan dengan hati-hati agar pembungkusnya tidak bocor. Jika suhu melebihi $4{ }^{\circ} \mathrm{C}$, mungkin perlu mengukur suhu internal sebelum menerima produk. Dalam hal ini, probe termometer harus dibersihkan dengan kapas alkohol sebelum mengukur suhu.

10. Periksa tanggal barang yang mudah rusak untuk memastikan keamanan dan kualitas, dan bahwa produk tidak melewati tanggal terbaik sebelum tanggal kadaluarsa.

11. Periksa integritas kemasan makanan.

12. Periksa kebersihan tempat dan wadah pengiriman lainnya sebelum menerima produk. Tolak makanan yang dikirim dalam tempat kotor.

13. Memberi label atau stempel wadah makanan dengan tanggal penerimaan.

14. Menggunakan First-In-First-Out, pastikan bahwa produk yang baru diterima ditempatkan di belakang stok saat ini.

15. selanjutnya melakukan corrective action apabila ada kesalahan atau kerusakan bahan baku makanan.. Obyek penelitian ini dilakukan di Danau Dariza Resort, Sabda Alam Resort, Sumber Alam Resort dan Sampireun Resort. Pendekatan penelitian ini dilakukan dengan menggunakan pendekatan studi kasus. Menurut Creswell (2015), studi kasus merupakan salah satu jenis pendekatan yang menelaah sebuah "kasus" tertentu dalam 
konteks atau setting kehidupan nyata kontemporer. Menurut Bungin (2007), salah satu yang menjadi landasan penelitian kualitatif adalah deskriptif, artinya penelitian deskriptif kualitatif bertujuan untuk menggambarkan, meringkas berbagai kondisi, berbagai situasi atau berbagai realitas fenomena sosial yang ada di masyarakat yang menjadi obyek penelitian dan berupaya sebagai ciri, karakter, sifat model, tanda gambaran tentang kondisi, situasi ataupun fenomena tertentu.

\section{Data, Instrumen dan Teknik Pengumpulan Data} adalah:

Untuk memperoleh data, sumber data yang digunakan dalam penelitian ini

1. Wawancara

Wawancara adalah cara pengumpulan data dengan mengajukan pertanyaan kepada responden secara langsung (Siswanto, 2011). Peneliti mengadakan tanya jawab dengan para informan untuk memperoleh data mengenai halhal yang ada kaitannya dengan masalah dalam penelitian ini. Dalam hal melakukan wawancara digunakan pedoman pertanyaan yang disusun berdasarkan kepentingan masalah yang diteliti. Selain itu peneliti mengumpulkan data melalui wawancara mendalam, yaitu suatu kegiatan yang dilakukan untuk mendapatkan informasi secara langsung dengan mengajukan pertanyaan antara pewawancara dengan yang diwawancarai. Bahkan keduanya dapat dilakukan bersamaan, di mana wawancara dapat digunakan untuk menggali lebih dalam lagi data yang didapat dari observasi. Seperti yang dikemukakan Sugiyono (2006) yang mengatakan bahwa dalam penelitian kualitatif, sering menggabungkan teknik observasi partisipatif dengan wawancara mendalam. Selama melakukan observasi, peneliti juga melakukan wawancara kepada orang-orang yang ada di dalamnya. Informan dalam penelitian ini yaitu bagian receiving clerk, pemasok dan executive chef di Danau Dariza Resort, Sabda Alam Resort, Sumber Alam Resort dan Sampireun Resort karena dianggap akan memahami dan mendukung pemberian data dan informasi yang mendalam terhadap fenomena yang terjadi dalam penelitian ini mengenai prosedur penerimaan bahan baku makanan perishable.

2. Observasi

Menurut Arikunto (2006), observasi atau pengamatan meliputi kegiatan pemuatan perhatian terhadap suatu obyek dengan menggunakan seluruh alat indera. Mengobservasi dapat dilakukan melalui penglihatan, penciuman, pendengaran, peraba dan pengecap. Observasi dapat dilakukan dengan tes, kuesioner, rekaman gambar, dan rekaman suara. Bungin (2006) mengemukakan beberapa bentuk observasi yang dapat digunakan dalam penelitian kualitatif, yaitu observasi partisipasi, observasi tidak terstruktur, dan observasi kelompok tidak terstruktur. Menurut Susan dalam Sugiyono (2006) dalam observasi partisipatif peneliti mengamati apa yang dikerjakan orang, mendengarkan apa yang mereka ucapkan, dan berpartisipasi dalam aktifitas mereka. Jadi Observasi partisipasi merupakan metode pengumpulan data yang digunakan untuk mendapatkan data penelitian melalui pengamatan dan pengindraan dimana observer atau peneliti benar- 
.

benar berada dalam keseharian pelaku yang diteliti atau informan, keberadaan peneliti dapat terlibat secara aktif maupun tidak aktif. Teknik ini digunakan secara langsung tentang hasil dari proses receiving di Danau Dariza Resort, Sumber Alam Resort, Sampireun Resort dan Sabda Alam Resort serta untuk mengetahui pendukung dan hambatan dalam pelaksanaannya.

3. Penelitian Kepustakaan

Penelitian kepustakaan merupakan cara untuk mengumpulkan data dengan menggunakan dan mempelajari literatur buku-buku kepustakaan yang ada untuk mencari konsepsi-konsepsi dan teori-teori yang berhubungan erat dengan permasalahan. Studi kepustakaan bersumber pada laporan-laporan, dokumen-dokumen yang berhubungan dengan permasalahan yang diteliti.

4. Analisis Dokumen

Kata dokumen berasal dari bahasa latin yaitu docere, berarti mengajar. Sedangkan menurut istilah dokumen yaitu sumber tertulis bagi informasi sejarah sebagai kebalikan dari pada kesaksian lisan, artefak, peninggalanpeninggalan terlukis, dan petilasan-petilasan arkeologis. Studi dokumen merupakan pelengkap dari penggunaan metode observasi dan wawancara (Gunawan, 2013). Pengamatan wawancara mendalam dapat pula dilengkapi dengan analisis dokumen seperti otobiografi, catatan harian, surat-surat pribadi, cacatan pengadilan, berita koran, artikel majalah, brosur, buletin, dan foto-foto (Mulyana, 2007). Hal ini dimaksudkan bahwa dokumentasi dilakukan untuk memperoleh data yang berkaitan dengan FSMS di Hotel area kabupaten Garut.

\section{Tempat dan Waktu Penelitian}

Penelitian ini dilakukan di empat resort hotel di Kabupaten Garut, yaitu di Danau Dariza Resort, Sumber Alam Resort, Sabda Alam Resort dan Kampung Sampireun Resort. Penelitian ini dilakukan dari Bulan Mei sampai dengan Bulan Juli 2020.

\section{Teknik Sampling}

Dalam penelitian kualitatif teknik sampling yang sering digunakan adalah purposive sampling. Purposive sampling adalah teknik pengambilan sampel sumber data dengan pertimbangan tertentu. Perkembangan tertentu ini misalnya orang tersebut yang dianggap tahu tentang apa yang kita harapkan atau mungkin dia sebagai penguasa sehingga akan memudahkan peneliti menjelajahi obyek atau situasi yang diteliti. Atau dengan kata lain pengambilan sampel diambil berdasarkan kebutuhan penelitian. Dalam penelitian ini penulis akan menggunakan teknik purposive sampling. Teknik sampling dalam penelitian kualitatif jelas berbeda dengan yang non kualitatif. Menurut Moleong (2005) sampel dalam penelitian kualitatif bukan dinamakan responden, tetapi sebagai narasumber, atau partisipan, informan, teman dan guru dalam penelitian. Sampel dalam penelitian kualitatif juga bukan disebut sampel statistik, tetapi sampel teoritis karena tujuan penelitian kualitatif adalah untuk menghasilkan teori. Sampling dalam penelitian kualitatif adalah pilihan penelitian meliputi aspek apa, dari peristiwa apa, dan siapa yang dijadikan fokus pada suatu saat dan situasi tertentu, karena itu dilakukan secara terus menerus sepanjang penelitian. Tujuannya yaitu memilih partisipan 
yang menjadi informan dan memberi sumbangsih terhadap pemahaman peneliti atas fenomena yang ada, Leo (2013). Sampel dari penelitian ini terdapat empat orang dari masing-masing lokasi penelitian yang juga berupa informan dalam penelitian ini, yaitu:

1. Danau Dariza Resort: 1 executive chef, 1 pemasok, 2 receiving clerk

2. Sabda Alam Resort: 1 executive chef, 1 pemasok, 2 receiving clerk

3. Sumber Alam Resort: 1 executive chef, 1 pemasok, 2 receiving clerk

4. Kampung Sampireun Resort: 1 executive chef, 1 pemasok, 2 receiving clerk

Dalam hal ini, peneliti memutuskan untuk memilih informan-informan tersebut karena executive chef berperan penting dan memiliki pengetahuan mengenai semua proses food cycle dimana proses ini salah satunya adalah proses penerimaan bahan baku makanan. Receiving clerk memiliki tanggung jawab atas proses penerimaan bahan baku makanan di hotel beserta dengan kegiatannya. Pemasok akan dimintai keterangan mengenai proses pengiriman bahan baku makanan ke hotel dan kualitas bahan makanan yang mereka kirimkan.

\section{Teknik Analisis Data}

Alat pengumpul data dilakukan dengan checklist dan pedoman wawancara. Checklist atau daftar cek adalah satu daftar yang berisi subjek dan aspek-aspek yang akan diamati (Riduwan, 2011). Checklist dapat menjamin bahwa peneliti mencatat tiap-tiap kejadian sekecil apapun yang dianggap penting. Bermacam-macam aspek perbuatan yang biasanya dicantumkan dalam daftar cek sehinga pengamat hanya memberikan checklist pada tiap-tiap aspek tersebut sesuai dengan hasil pengamatannya. Pedoman Wawancara dilakukan secara terstruktur dan tidak terstruktur, dan dapat dilakukan dengan tatap muka (face to face) maupun menggunakan telepon (Sugiyono, 2006). Dalam penelitian ini data-data yang diteliti adalah gambaran umum, proses penerimaan bahan baku makanan, alat-alat dalam proses penerimaan bahan baku makanan, proses pengiriman bahan baku makanan dari pemasok di Danau Dariza Resort, Sabda Alam Resort, Sumber Alam Resort dan Kampung Sampireun Resort. Proses analisis data yang dilakukan oleh peneliti adalah dengan langkah-langkah sebagai berikut:

1. Reduksi data (data reduction)

Reduksi data adalah merupakan analisis data yang menggolongkan data dengan cara sedemikian rupa hingga kesimpulan finalnya dapat ditarik kesimpulan (verifikasi). Data yang diperoleh dari lapangan langsung ditulis dengan rinci dan sistematis setiap selesai mengumpulkan data. Laporanlaporan itu perlu direduksi, yaitu dengan memilih hal-hal pokok yang sesuai dengan fokus penelitian agar mudah untuk menyimpulkannya. Reduksi data dilakukan untuk mempermudah peneliti dalam mencari kembali data yang diperoleh bila diperlukan serta membantu dalam memberikan kode kepada aspek-aspek tertentu.

2. Penyajian Data (data display)

Setelah data direduksi, maka langkah selanjutnya adalah penyajian data. Penyajian data menurut Nasution (1988) yaitu mengumpulkan data atau informasi secara tersusun yang memberi kemungkinan adanya penarikan kesimpulan dan pengambilan tindakan. Data yang sudah ada disusun 
dengan menggunakan teks yang bersifat naratif, selain itu bisa juga bersifat matriks, grafik, dan chart. Penyajian data dilakukan dengan alasan supaya peneliti dapat menguasai data dan tidak tenggelam dalam tumpukan. Selain itu juga supaya peneliti mudah dalam memahami yang telah terjadi dan dapat merencanakan apa yang akan dilakukan selanjutnya.

3. Verifikasi (verification)

Verifikasi merupakan rangkaian analisis data puncak. Kesimpulan dalam penelitian kualitatif membutuhkan verifikasi selama penelitian berlangsung. Verifikasi dimaksudkan untuk menghasilkan kesimpulan yang valid. Oleh karena itu, ada baiknya sebuah kesimpulan ditinjau ulang dengan cara memverifikasi kembali catatan-catatan selama penelitian dan mencari pola, tema, model, hubungan dan persamaan untuk diambil sebuah kesimpulan.

\section{Pengujian Keabsahan Data}

Prosedur yang digunakan dalam uji keabsahan data dalam penelitian kualitatif adalah pengumpulan data hingga titik jenuh (triangulasi data). Teknik triangulasi data yang merujuk pada suatu proses pemanfaatan persepsi yang beragam untuk mengklarifikasi makna, memverifikasi kemungkinan pengulangan dari suatu observasi atau interpretasi dan untuk mengklarifikasi makna dengan cara mengidentifikasi cara pandang yang berbeda terhadap berbagai fenomena, Moleong (2004), berikut prosesnya:

1. Pengecekan ulang informasi dari sumber di depan umum dan pribadi.

2. Perbandingan hasil wawancara dengan dokumen.

Dialog dengan berbagai pihak untuk mendapatkan pemahaman terkait objek.

\section{HASIL DAN PEMBAHASAN}

Hasil penelitian dan pembahasan meliputi aspek: 1) Prosedur Receiving di Resort Kabupaten Garut (Danau Dariza Resort, Sumber Alam Resort, Sabda Alam Resort, Kampung Sampireun Resort) dan 2) Penerapan Prosedur Receiving Pada Fsms Di Resort Kabupaten Garut (Danau Dariza Resort, Sumber Alam Resort, Sabda Alam Resort, Kampung Sampireun Resort).

\section{Prosedur Receiving Di Resort Kabupaten Garut (Danau Dariza Resort, Sumber Alam Resort, Sabda Alam Resort, Kampung Sampireun Resort)}

\section{Prosedur Receiving Food Safety Di Danau Dariza Resort}

Dari hasil wawancara penulis dengan Bapak Asep selaku chef executive dari Dariza Resort, para karyawan makanan yang berhubungan dengan kitchen, telah dilatih secara internal dalam perihal safety food training tetapi belum memiliki sertifikat. Prosedur receiving di Dariza Resort ini dilakukan dengan cara yaitu sebelum melaksankan tugas dalam penerimaan barang/receiving, diberikan Purchase Order (PO) oleh pihak purchasing yang nantinya akan digunakan sebagai dasar penerimaan barang. Purchase Order berisi nama supplier, tanggal order, nomer PO, nomer PO, department yang memesan, nama barang, jumlah yang dipesan, unit, harga per unit, jumlah harga per unit, dan total harga keseluruhan. Untuk daily market list sebelum diserahkan ke receiving tentunya sudah mendapat tandatangan sebagai bukti telah disetujui baik dari Financial Controller ataupun 
.

purchasing. Hal ini untuk memastikan bahwa semua daftar telah benar dan apabila ada yang kurang jelas bisa segara ditanyakan ke purchasing. Menerima barang yang datang dari pemasok atas dasar pesanan dan memeriksanya terlebih dahulu baik jenis, jumlah, kualitas, tanggal kadaluarasa, dan harga apakah sudah sesuai dengan spesifikasi atau tidak. Menginformasikan kepada chef atas kedatangan jenis daging, unggas ataupun makanan laut yang memastikan bahwa yang datang layak untuk diterima atas persetujuan chef. Supplier dalam pengiriman ke Dariza Resort masih belum memiliki truk pendingin, mereka masih mengantarkan bahan baku makanan dengan transportasi pengangkut makanan tanpa pendingin, kecuali untuk produk makanan bungkus atau frozen food. Untuk sayuran yang datang dan telah dicek dan ditimbang akan dicuci oleh supplier dan meletakannya pada keranjang yang telah disedikan dan memasukkannya kedalam chiler yang nantinya akan ditata oleh bagian kitchen.

\section{Prosedur Receiving Food Safety Di Sumber Alam Resort}

Dari hasil wawancara penulis dengan Bapak Setiawan bagian chef executive, prosedur receiving di Sumber Alam Resort berawal dari Market list ke bagian purchasing untuk mendata bahan baku yang akan dipesan, lalu dilanjutkan ke supplier, ketika sudah tersedia di supplier, bahan baku makanan yang telah dipesan akan dicek oleh quality control lalu diterima oleh bagian receiving. Jadi kontrol sistem untuk penerimaan bahan baku makanan di Sumber Alam resort dilakukan oleh dua bagian yaitu quality control dan bagian receiving. Bahan baku makanan yang diterima dicek sesuai ketetapan suhu pada setiap bahan baku makanan. Kualifikasi yang masuk ke dapur harus sudah siap olah. Bagian receiving harus mengerti spesifikasi bahan baku makanan yang dibutuhkan. Apabila sudah masuk pada bagian receiving, ketika bahan baku makanan diterima di dapur, akan ada pengontrolan bahan baku makanan lagi. Apabila tidak masuk ke kualifikasi bahan makanan yang baik, akan dikembalikan lagi ke bagian receiving. Barang yang direject akan dikembalikan pada saat itu juga. Dari receiving, bahan baku makanan perishable akan dimasukan ke freezer terlebih dahulu. Bahan baku dicuci dulu pada bagian receiving sebelum masuk ke kitchen. Petugas receiving di Sumber Alam Resort tidak memiliki sertifikat pelatihan untuk receiving bahan baku akan tetapi sudah diberikan pelatihan internal mengenai food safety.

\section{Prosedur Receiving Food Safety Di Sabda Alam Resort}

Dari hasil wawancara penulis dengan Ibu Wenny bagian receiving clerk di Sabda Alam, untuk penyediaan makanan di Sabda Alam berbeda dengan hotel-hotel lainnya, di Sabda Alam hanya menyediakan beberapa makanan saja dibandingkan dengan hotel lain, namun dari segi kehalalan makanan, Sabda Alam telah memiliki sertifikat. Dalam kasus ini, hal yang terpenting adalah mengenai keamanan penerimaan (receiving) makanan perishable product (seperti daging, sayur dan buah). Sabda Alam hanya menyediakan beberapa item makanan, untuk penerimaan nya sebagian diberikan pada store keeper namun sebagian langsung diberikan pada bagian dapur. Proses penerimaan bahan baku makanan di Sabda Alam tidak terlalu tinggi, karena pemesanan makanan disesuaikan dengan kebutuhan pada saat itu saja. Dari sarana prasana penerimaan makanan di Sabda Alam, untuk sementara waktu tidak menyediakan gudang (storage) karena penerimaan bahan makanan dari supplier langsung di arahkan ke dapur, karena pada saat ini pembelian bahan 
bakunya pun hanya sedikit (1/2-1kg saja per hari), karenanya makanan yang diterima langsung diolah di dapur, untuk meminimalisir biaya. Penerimaan bahan baku makanan dilakukan pada pagi hari setiap pukul 6.00. Bagian penerima makanan (receiver) memeriksa kualitas dari makanan tersebut, setelah itu tidak dimasukan dalam storage karena langsung diolah. Sabda Alam Resort ini masih dalam proses perkembangan, maka dari itu dari segi sarana dan prasarana penerimaan bahan baku makanan, masih belum maksimal. Namun biasanya, penerimaan bahan baku makanan langsung di simpan di gudang, namun tidak bisa tahan lama, langsung disebarkan ke tiap department yang juga memiliki gudang, namun untuk truk chiller atau pendingin dan dari kadar pengatur suhu dan udara ruangan untuk keamanan dan kesterilan makanannya, Sabda Alam masih belum memiliki fasilitasnya.

\section{Prosedur Receiving Food Safety Di Kampung Sampireun Resort}

Berdasarkan wawancara penulis dengan Bapak Yogi sebagai executive chef. Prosedur Receiving yang dilakukan di Kampung Sampireun Resort pertama kali dilakukan oleh bagian Kitchen Admin yang akan mengirimkan daftar bahan baku makanan yang akan dipesan kepada Supplier, lalu bahan baku makanan akan diterima langsung di dapur dan diterima oleh bagian receiving. Lalu di dapur, bahan makanan yang diterima akan di kilo, apabila ada yg kurang, akan diberitahukan langsung kepada suppliernya, lalu bahan baku makanan yang telah diterima dicatat di kontra bon, lalu untuk sayuran, sayuran akan dimasukkan ke dalam kontainer, dicuci, dikeringkan dan di masukan ke chiller. Untuk daging, pertama kali akan dikilo dan dicatat dibon, lalu dimasukan ke dalam freezer. Bahan baku di periksa sesuai spesifikasi, suhu, berat dan kadaluarsanya. Bahan baku dipindahkan ke tempatnya di bagian hotel pada saat diterima. Sayuran dan buah dipakaikan disinfektan. Karyawan di Kampung Sampireun Resort sudah memiliki sertifikat keamanan makanan. Bahan baku yang diterima dimasukan ke dalam pendingin. Bagian yang memilih supplier adalah kitchen admin. Pada saat memlih, karyawan telah menelaah supplier terlebih dahulu berdasarkan kesiapan supplier tersebut. Supplier yang ditunjuk memiliki alat transportasi berpendingin untuk frozen food. Akan tetapi untuk daging dan sayuran tidak, karena masih memakai motor/kolbak. Bahan baku makanan yang tidak segar atau tidak sesuai spesifikasi akan dikembalikan kepada supplier. Proses ini biasanya dilakukan di pagi hari dan sore hari.

\section{Penerapan Prosedur Receiving Pada Fsms Di Resort Kabupaten Garut (Danau Dariza Resort, Sumber Alam Resort, Sabda Alam Resort, Kampung Sampireun Resort)}

Berikut ini merupakan kajian pada hotel di area Kabupaten Garut sesuai dengan penetapan FSMS berdasarkan pada checking list receiving pada safety food HAACP (2017): 
Tabel 1.

\section{Checklist FSMS prosedur Receiving pada Danau Dariza Resort}

\begin{tabular}{|c|c|c|c|}
\hline No. & Pernyataan & Ya & Tidak \\
\hline 1. & $\begin{array}{l}\text { Karyawan receiver telah memiliki sertifikat mengenai Food } \\
\text { Safety }\end{array}$ & & $\checkmark$ \\
\hline 2. & $\begin{array}{l}\text { Memeriksa truk pengiriman saat tiba untuk memastikan } \\
\text { bahwa truk tersebut bersih, bebas dari bau busuk, hama, dan } \\
\text { terorganisir untuk mencegah kontaminasi silang. Pastikan } \\
\text { makanan yang didinginkan dan dibekukan dikirim dengan } \\
\text { truk yang sesuai. }\end{array}$ & $\checkmark$ & \\
\hline 3. & $\begin{array}{l}\text { Apakah suhu interior truk berpendingin dan freezer pada saat } \\
\text { penerimaan bahan baku makanan sesuai berikut ini: } \\
\text { - Suhu bahan mentah pada saat kedatangan: } 4^{\circ} \mathrm{C} \text { atau } \\
\text { lebih rendah (makanan dingin) / beku seluruhnya } \\
\text { (makanan beku) } \\
\text { - Truk berpendingin untuk buah, daging dan sayur. }\end{array}$ & & $\checkmark$ \\
\hline 4. & $\begin{array}{l}\text { Konfirmasi nama vendor, hari dan waktu pengiriman, serta } \\
\text { identifikasi pengemudi sebelum menerima pengiriman. Jika } \\
\text { nama pengemudi berbeda dengan yang tertera pada jadwal } \\
\text { pengiriman, segera hubungi vendornya }\end{array}$ & $\checkmark$ & \\
\hline 5. & $\begin{array}{l}\text { Periksa makanan beku untuk memastikan bahwa semuanya } \\
\text { beku dan tidak menunjukkan tanda-tanda mencair }\end{array}$ & $\checkmark$ & \\
\hline 6. & $\begin{array}{l}\text { Periksa buah dan sayur untuk memastikan dalam keadaan } \\
\text { baik dan bebas hama }\end{array}$ & $\checkmark$ & \\
\hline 7. & $\begin{array}{l}\text { Periksa suhu makanan yang didinginkan (daging segar, ikan, } \\
\text { produk unggas), untuk produk kemasan, masukkan } \\
\text { termometer makanan di antara dua kemasan dengan hati-hati } \\
\text { agar pembungkusnya tidak bocor. Jika suhu melebihi } 4{ }^{\circ} \mathrm{C} \text {, }\end{array}$ & $\checkmark$ & \\
\hline 8. & $\begin{array}{l}\text { Periksa tanggal kadaluwarsa barang yang mudah rusak untuk } \\
\text { memastikan keamanan dan kualitas, dan bahwa produk tidak } \\
\text { melewati tanggal terbaik sebelum tanggal kadaluarsa. }\end{array}$ & $\checkmark$ & \\
\hline 9. & Periksa integritas kemasan makanan & $\checkmark$ & \\
\hline 10. & $\begin{array}{l}\text { Periksa kebersihan tempat dan wadah pengiriman lainnya } \\
\text { sebelum menerima produk. Tolak makanan yang dikirim } \\
\text { dalam tempat kotor }\end{array}$ & $\checkmark$ & \\
\hline 11. & $\begin{array}{l}\text { Memberi label atau stempel wadah makanan dengan tanggal } \\
\text { penerimaan }\end{array}$ & & $\checkmark$ \\
\hline 12. & $\begin{array}{l}\text { Menggunakan First-In-First-Out, pastikan bahwa produk } \\
\text { yang baru diterima ditempatkan di belakang stok saat ini }\end{array}$ & $\checkmark$ & \\
\hline 13. & $\begin{array}{l}\text { Melakukan corrective action apabila ada kesalahan atau } \\
\text { kerusakan bahan baku makanan. }\end{array}$ & $\checkmark$ & \\
\hline
\end{tabular}

Sumber: Olahan Data Penulis (2020) 
Tabel 2.

Checklist FSMS prosedur Receiving pada Sumber Alam Resort

\begin{tabular}{|c|c|c|c|}
\hline No. & Pernyataan & Ya & Tidak \\
\hline 1. & $\begin{array}{l}\text { Karyawan receiver telah memiliki sertifikat mengenai } \\
\text { Food Safety }\end{array}$ & $\checkmark$ & \\
\hline 2. & $\begin{array}{l}\text { Memeriksa truk pengiriman saat tiba untuk memastikan } \\
\text { bahwa truk tersebut bersih, bebas dari bau busuk, hama, } \\
\text { dan terorganisir untuk mencegah kontaminasi silang. } \\
\text { Pastikan makanan yang didinginkan dan dibekukan } \\
\text { dikirim dengan truk yang sesuai. }\end{array}$ & $\checkmark$ & \\
\hline 3. & $\begin{array}{l}\text { Apakah suhu interior truk berpendingin dan freezer pada } \\
\text { saat penerimaan bahan baku makanan sesuai berikut ini: } \\
\text { - Suhu bahan mentah pada saat kedatangan: } 4{ }^{\circ} \mathrm{C} \\
\text { atau lebih rendah (makanan dingin) / beku } \\
\text { seluruhnya (makanan beku) } \\
\text { - Truk berpendingin untuk buah, daging dan sayur. }\end{array}$ & & $\checkmark$ \\
\hline 4. & $\begin{array}{l}\text { Konfirmasi nama vendor, hari dan waktu pengiriman, } \\
\text { serta identifikasi pengemudi sebelum menerima } \\
\text { pengiriman. Jika nama pengemudi berbeda dengan yang } \\
\text { tertera pada jadwal pengiriman, segera hubungi } \\
\text { vendornya }\end{array}$ & $\checkmark$ & \\
\hline 5. & $\begin{array}{l}\text { Periksa makanan beku untuk memastikan bahwa } \\
\text { semuanya beku dan tidak menunjukkan tanda-tanda } \\
\text { mencair }\end{array}$ & $\checkmark$ & \\
\hline 6. & $\begin{array}{l}\text { Periksa buah dan sayur untuk memastikan dalam keadaan } \\
\text { baik dan bebas hama }\end{array}$ & $\checkmark$ & \\
\hline 7. & $\begin{array}{l}\text { Periksa suhu makanan yang didinginkan (daging segar, } \\
\text { ikan, produk unggas), untuk produk kemasan, masukkan } \\
\text { termometer makanan di antara dua kemasan dengan hati- } \\
\text { hati agar pembungkusnya tidak bocor. Jika suhu melebihi } \\
4^{\circ} \mathrm{C} \text {, }\end{array}$ & $\checkmark$ & \\
\hline 8. & $\begin{array}{l}\text { Periksa tanggal kadaluwarsa barang yang mudah rusak } \\
\text { untuk memastikan keamanan dan kualitas, dan bahwa } \\
\text { produk tidak melewati tanggal terbaik sebelum tanggal } \\
\text { kadaluarsa. }\end{array}$ & $\checkmark$ & \\
\hline 9. & Periksa integritas kemasan makanan & $\checkmark$ & \\
\hline 10. & $\begin{array}{l}\text { Periksa kebersihan tempat dan wadah pengiriman lainnya } \\
\text { sebelum menerima produk. Tolak makanan yang dikirim } \\
\text { dalam tempat kotor }\end{array}$ & $\checkmark$ & \\
\hline 11. & $\begin{array}{l}\text { Memberi label atau stempel wadah makanan dengan } \\
\text { tanggal penerimaan }\end{array}$ & & $\checkmark$ \\
\hline 12. & $\begin{array}{l}\text { Menggunakan First-In-First-Out, pastikan bahwa produk } \\
\text { yang baru diterima ditempatkan di belakang stok saat ini }\end{array}$ & $\checkmark$ & \\
\hline 13. & $\begin{array}{l}\text { Melakukan corrective action apabila ada kesalahan atau } \\
\text { kerusakan bahan baku makanan. }\end{array}$ & $\checkmark$ & \\
\hline
\end{tabular}

Sumber: Olahan Data Penulis (2020) 
Tabel 3.

\section{Checklist FSMS prosedur Receiving pada Sabda Alam Resort}

\begin{tabular}{|c|c|c|c|}
\hline No. & Pernyataan & Ya & Tidak \\
\hline 1. & $\begin{array}{l}\text { Karyawan receiver telah memiliki sertifikat mengenai } \\
\text { Food Safety }\end{array}$ & $\checkmark$ & \\
\hline 2. & $\begin{array}{l}\text { Memeriksa truk pengiriman saat tiba untuk memastikan } \\
\text { bahwa truk tersebut bersih, bebas dari bau busuk, hama, } \\
\text { dan terorganisir untuk mencegah kontaminasi silang. } \\
\text { Pastikan makanan yang didinginkan dan dibekukan } \\
\text { dikirim dengan truk yang sesuai. }\end{array}$ & $\checkmark$ & \\
\hline 3. & $\begin{array}{l}\text { Apakah suhu interior truk berpendingin dan freezer pada } \\
\text { saat penerimaan bahan baku makanan sesuai berikut ini: } \\
\text { - Suhu bahan mentah pada saat kedatangan: } 4{ }^{\circ} \mathrm{C} \\
\text { atau lebih rendah (makanan dingin) / beku } \\
\text { seluruhnya (makanan beku) } \\
\text { - Truk berpendingin untuk buah, daging dan sayur. }\end{array}$ & & $\checkmark$ \\
\hline 4. & $\begin{array}{l}\text { Konfirmasi nama vendor, hari dan waktu pengiriman, } \\
\text { serta identifikasi pengemudi sebelum menerima } \\
\text { pengiriman. Jika nama pengemudi berbeda dengan yang } \\
\text { tertera pada jadwal pengiriman, segera hubungi } \\
\text { vendornya }\end{array}$ & $\checkmark$ & \\
\hline 5. & $\begin{array}{l}\text { Periksa makanan beku untuk memastikan bahwa } \\
\text { semuanya beku dan tidak menunjukkan tanda-tanda } \\
\text { mencair }\end{array}$ & $\checkmark$ & \\
\hline 6. & $\begin{array}{l}\text { Periksa buah dan sayur untuk memastikan dalam keadaan } \\
\text { baik dan bebas hama }\end{array}$ & $\checkmark$ & \\
\hline 7. & $\begin{array}{l}\text { Periksa suhu makanan yang didinginkan (daging segar, } \\
\text { ikan, produk unggas), untuk produk kemasan, masukkan } \\
\text { termometer makanan di antara dua kemasan dengan hati- } \\
\text { hati agar pembungkusnya tidak bocor. Jika suhu melebihi } \\
4^{\circ} \mathrm{C} \text {, }\end{array}$ & $\checkmark$ & \\
\hline 8. & $\begin{array}{l}\text { Periksa tanggal kadaluwarsa barang yang mudah rusak } \\
\text { untuk memastikan keamanan dan kualitas, dan bahwa } \\
\text { produk tidak melewati tanggal terbaik sebelum tanggal } \\
\text { kadaluarsa. }\end{array}$ & $\checkmark$ & \\
\hline 9. & Periksa integritas kemasan makanan & $\checkmark$ & \\
\hline 10. & $\begin{array}{l}\text { Periksa kebersihan tempat dan wadah pengiriman lainnya } \\
\text { sebelum menerima produk. Tolak makanan yang dikirim } \\
\text { dalam tempat kotor }\end{array}$ & $\checkmark$ & \\
\hline 11. & $\begin{array}{l}\text { Memberi label atau stempel wadah makanan dengan } \\
\text { tanggal penerimaan }\end{array}$ & & $\checkmark$ \\
\hline 12. & $\begin{array}{l}\text { Menggunakan First-In-First-Out, pastikan bahwa produk } \\
\text { yang baru diterima ditempatkan di belakang stok saat ini }\end{array}$ & $\checkmark$ & \\
\hline 13. & $\begin{array}{l}\text { Melakukan corrective action apabila ada kesalahan atau } \\
\text { kerusakan bahan baku makanan. }\end{array}$ & $\checkmark$ & \\
\hline
\end{tabular}

Sumber: Olahan Data Penulis (2020) 
Tabel 4.

\section{Checklist FSMS prosedur Receiving pada Kampung Sampireun Resort}

\begin{tabular}{|c|c|c|c|}
\hline No. & Pernyataan & $\mathrm{Ya}$ & Tidak \\
\hline 1. & $\begin{array}{l}\text { Karyawan receiver telah memiliki sertifikat mengenai Food } \\
\text { Safety }\end{array}$ & & $\checkmark$ \\
\hline 2. & $\begin{array}{l}\text { Memeriksa truk pengiriman saat tiba untuk memastikan } \\
\text { bahwa truk tersebut bersih, bebas dari bau busuk, hama, dan } \\
\text { terorganisir untuk mencegah kontaminasi silang. Pastikan } \\
\text { makanan yang didinginkan dan dibekukan dikirim dengan } \\
\text { truk yang sesuai. }\end{array}$ & $\checkmark$ & \\
\hline 3. & $\begin{array}{l}\text { Apakah suhu interior truk berpendingin dan freezer pada } \\
\text { saat penerimaan bahan baku makanan sesuai berikut ini: } \\
\text { - Suhu bahan mentah pada saat kedatangan: } 4{ }^{\circ} \mathrm{C} \\
\text { atau lebih rendah (makanan dingin) / beku } \\
\text { seluruhnya (makanan beku) } \\
\text { - Truk berpendingin untuk buah, daging dan sayur. }\end{array}$ & & $\checkmark$ \\
\hline 4. & $\begin{array}{l}\text { Konfirmasi nama vendor, hari dan waktu pengiriman, serta } \\
\text { identifikasi pengemudi sebelum menerima pengiriman. Jika } \\
\text { nama pengemudi berbeda dengan yang tertera pada jadwal } \\
\text { pengiriman, segera hubungi vendornya }\end{array}$ & $\checkmark$ & \\
\hline 5. & $\begin{array}{l}\text { Periksa makanan beku untuk memastikan bahwa semuanya } \\
\text { beku dan tidak menunjukkan tanda-tanda mencair }\end{array}$ & $\checkmark$ & \\
\hline 6. & $\begin{array}{l}\text { Periksa buah dan sayur untuk memastikan dalam keadaan } \\
\text { baik dan bebas hama }\end{array}$ & $\checkmark$ & \\
\hline 7. & $\begin{array}{l}\text { Periksa suhu makanan yang didinginkan (daging segar, } \\
\text { ikan, produk unggas), untuk produk kemasan, masukkan } \\
\text { termometer makanan di antara dua kemasan dengan hati- } \\
\text { hati agar pembungkusnya tidak bocor. Jika suhu melebihi } 4 \\
{ }^{\circ} \mathrm{C} \text {, }\end{array}$ & $\checkmark$ & \\
\hline 8. & $\begin{array}{l}\text { Periksa tanggal kadaluwarsa barang yang mudah rusak } \\
\text { untuk memastikan keamanan dan kualitas, dan bahwa } \\
\text { produk tidak melewati tanggal terbaik sebelum tanggal } \\
\text { kadaluarsa. }\end{array}$ & $\checkmark$ & \\
\hline 9. & Periksa integritas kemasan makanan & $\checkmark$ & \\
\hline 10. & $\begin{array}{l}\text { Periksa kebersihan tempat dan wadah pengiriman lainnya } \\
\text { sebelum menerima produk. Tolak makanan yang dikirim } \\
\text { dalam tempat kotor }\end{array}$ & $\checkmark$ & \\
\hline 11. & $\begin{array}{l}\text { Memberi label atau stempel wadah makanan dengan tanggal } \\
\text { penerimaan }\end{array}$ & & $\checkmark$ \\
\hline 12. & $\begin{array}{l}\text { Menggunakan First-In-First-Out, pastikan bahwa produk } \\
\text { yang baru diterima ditempatkan di belakang stok saat ini }\end{array}$ & $\checkmark$ & \\
\hline 13. & $\begin{array}{l}\text { Melakukan corrective action apabila ada kesalahan atau } \\
\text { kerusakan bahan baku makanan. }\end{array}$ & $\checkmark$ & \\
\hline
\end{tabular}

Sumber: Olahan Data Penulis (2020)

Dari hasil tabel checklist FSMS prosedur receiving pada Dariza Resort, Sumber Alam Resort, Sabda Alam Resort dan Kampung Sampireun Resort 
.

menunjukkan bahwa proses penerimaan sudah cukup baik, namun karyawan receiver pada Danau Dariza dan Kampung Sampireun belum memiliki sertifikat resmi Food Safety, hanya saja mereka telah mendapatkan pelatihan secara internal. Akan tetapi karyawan pada Sabda Alam Resort dan Sumber Alam Resort sudah memiliki sertifikat Food Safety secara resmi. Hal ini menegaskan bahwa, sertifikat food safety untuk karyawan sangat penting karena, karyawan berarti telah mengetahui segala prosedur dalam proses penerimaan bahan baku yang tepat. Menurut Purnomo (2006), metode terbaik dan paling efektif menjamin keamanan pangan adalah dengan menetapkan sistematik dan pelatihan dan pendidikan berkelanjutan kepada karyawan untuk penangan makanan di perhotelan dan industri pengolahan makanan, pengelola perhotelan dan pengolahan industri makanan. Hal lainnya mengenai pemeriksaan truk pengiriman saat tiba untuk memastikan bahwa truk tersebut bersih, bebas dari bau busuk, hama, dan terorganisir untuk mencegah kontaminasi, keempat hotel tersebut telah melakukannya dengan baik, karena mereka telah mengikuti prosedur pemeriksaan truk sebelum akhirnya bahan makanan diterima oleh receiver. Hal ini sangat penting dilakukan karena, dengan pemeriksaan ini, akan dipastikan bahwa bahan makanan yang akan diterima dan dimasak, tidak terkontaminasi dengan bahan berbahaya.

Terdapat kekurangan dari segi prosedur penerimaan bahan baku makanan persihable pada keempat hotel tersebut yaitu, pengiriman dari supplier kepada petugas penerima bahan baku makanan tidak memiliki chiller atau pendingin, hal ini sangat penting untuk diperhatikan karena hal ini akan sangat berbahaya apabila tidak diikuti prosedurnya, kehadiran dan pertumbuhan bakteri keracunan makanan selama pengiriman dapat terjadi khususnya untuk perishable product seperti daging segar, ikan, unggas yang memiliki spesifikasi suhu tertentu dalam proses pengiriman dari supplier terhadap receiver. Seperti yang disebutkan oleh Hoof et al. (1996) menyebutkan bahwa setiap makanan memiliki standar penyimpanan. Mereka juga menyatakan bahwa penyimpanan dirancang untuk menjaga kualitas produk sekaligus mengurangi kerugian akibat pencurian dan pembusukan. Cornelius dan Cronan (1997), hal ini juga harus sangat diperhatikan dalam pengiriman, karena bisa saja daging membusuk atau kualitasnya menurun akibat suhu yang tidak sesuai pada saat pengiriman perishable product. Dengan adanya kekurangan ini, tentu saja pada saat proses receiving ada pemeriksaan suhu makanan yang didinginkan (daging segar, ikan, produk unggas) akan tetapi jika suhu melebihi $4^{\circ} \mathrm{C}$, mungkin perlu mengukur suhu internal truk sebelum menerima produk, hal ini menyebabkan kualitas pengukuran suhu tidak maksimal ata tidak sesuai prosedur, karena vendor tidak memiliki truk pendingin untuk daging segar.

Dalam prosedur konfirmasi mengenai vendor atau supplier, mengenai hari dan waktu pengiriman, serta identifikasi pengemudi sebelum menerima pengiriman, keempat hotel tersebut telah melaksanakan proses dengan baik, mereka telah mengidentifikasi dan memilah vendor yang terpercaya untuk menyediakan kualitas bahan makanan yang baik. Hal ini penting diperhatikan karena, apabila ada kerusakan atau kualitas yang buruk, atatupun terjadi kesalahan dalam harga dll, pihak hotel dapat meminta pertanggung jawaban secara jelas dengan vendor. Karena inti dari kualitas sajian makanan yang baik berawal dari vendor. Hal lain dalam prosedur receiving ini yaitu pemeriksaan makanan beku untuk memastikan bahwa semuanya beku dan tidak menunjukkan tanda-tanda mencair, dalam hal ini 
.

mereka telah memeriksa keadaan frozen food yang dikirimkan oleh vendor saat penerimaan, dan akan selalu diperiksa kualitas makanan nya. Apakah pada saat dikirim, makanan tersebut sudah beku, dan ketika diterima harus tetap beku. Mereka juga memeriksa buah dan sayur untuk memastikan dalam keadaan baik dan bebas hama, sayur dan buah yang mereka terima diperiksa lalu dicuci dan disimpan pada chiller pada bagian storage atau kitchen. Pemeriksaan tanggal kadaluwarsa barang yang mudah rusak untuk memastikan keamanan dan kualitas, dan bahwa produk tidak melewati tanggal terbaik sebelum tanggal kadaluarsa selalu dilakukan dalam proses receiving pada keempat hotel tersebut. Integritas kemasan makanan dan kebersihan tempat dan wadah pengiriman lainnya sebelum menerima produk pun telah dilakukan. Hal ini dilakukan untuk menghindari kemasan rusak dan kontaminasi dengan benda asing (termasuk bakteri keracunan makanan) Kemasan harus utuh dan tidak ada benda asing yang terlihat, kendaraan pengiriman pun harus bersih dan higienis dan tidak digunakan untuk mengangkut bahan kimia yang dapat menyebabkan kerusakan pada bahan makanan atau menurunnya kualitas makanan.

Kekurangan lain yang terdapat pada resort hotel area Kabupaten Garut, yaitu tidak melakukan pemberian label atau stempel wadah makanan dengan tanggal penerimaan. Hal ini seharusnya dilakukan sesuai prosedur HAACP, karena sangat penting untuk melihat seberapa lama, bahan makanan yang diterima telah ada di dalam storage yang mempermudah bagian kitchen untuk menentukan bahan mana dulu yang seharusnya dipergunakan atau dimasak. Dan mengidentifikasi bahan makanan yang sekiranya telah terlalu lama berada di storage. Keempat hotel tersebut sudah menggunakan prosedur First-In-First-Out, untuk memastikan bahwa produk yang baru diterima ditempatkan di belakang stok saat ini, hal ini juga dapat mempermudah untuk penyimpanan dan pemilihan bahan baku makanan.

Secara umum, keempat hotel di area kabupaten garut selalu melakukan prosedur corrective action, dimana apabila ada kesalahan atau kerusakan bahan baku makanan, akan segera mereka kembalikan kepada vendor pada hari yang sama ketika mereka menerima barang dari vendor. Hal yang perlu diperhatikan dalam prosedur ini adalah apabila, bahan makanan tidak segar atau rusak, produk kadaluwarsa, bahan baku makanan bertanda pestisida dan forzen food yang telah membusuk.

\section{SIMPULAN}

Berdasarkan hasil penelitian, dapat ditarik kesimpulan penerapan food safety manajemen system pada proses penerimaan bahan baku makanan pada Danau Dariza Resort, Sabda Alam Resort, Sumber Alam Resort dan Kampung Sampireun Resort belum memenuhi standar yang diharapkan, karena hasil penelitian menunjukkan masih terdapat beberapa kekurangan dalam prosedur penerimaan bahan baku makanan pada keempat lokasi tersebut diantaranya adalah karyawan tidak memiliki sertifikat food safety, tidak adanya truk berpendingin untuk pengiriman bahan baku makanan dan tidak adanya pelabelan pada wadah makanan dengan tanggal penerimaan. Hal ini sangat krusial karena dapat mengakibatkan penerimaan bahan baku makanan dalam jumlah besar tidak 
teridentifikasi bahan makanan mana yang harus digunakan terlebih dahulu, sehingga ada potensi makanan yang mudah rusak menjadi busuk.

Dengan hasil penelitian ini, Hotel Resort di Area Kabupaten Garut memberikan pelatihan resmi bersertifikat untuk para pegawai di hotel khususnya pada bagian FSMS, hal ini sangat penting karena, karyawan berarti telah mengetahui segala prosedur dalam proses penerimaan bahan baku yang tepat. Selain itu juga dapat mempertimbangkan memilih vendor yang memiliki truk pendingin untuk pengiriman bahan baku makanan khususnya untuk persihable food, hal ini sangat penting untuk diperhatikan karena akan sangat berbahaya apabila tidak diikuti prosedurnya, seperti adanya racun atau virus dalam makanan dan membuat bahan baku makanan cepat membusuk. Pemberian label atau stempel wadah makanan dengan tanggal penerimaan, hal ini seharusnya dilakukan sesuai prosedur HAACP, karena sangat penting untuk melihat seberapa lama, bahan makanan yang diterima telah ada di dalam storage yang mempermudah bagian kitchen untuk menentukan bahan mana dulu yang seharusnya dipergunakan atau dimasak dan mengidentifikasi bahan makanan yang sekiranya telah terlalu lama berada di storage.

\section{DAFTAR PUSTAKA}

Akabanda, F., Hlortsi, E.H and Owusu-Kwarteng, J. (2017). Food safety knowledge, attitudes and practices of institutional foodhandlers in Ghana. BMC Public Health, vol. 17, no. 1, p. 40.

Alagiyawanna, A. (2018). Effects of multiple interventions on the hygienic standards of food handling establishments. MOJ Public Health, vol. 7, no. 6, pp. 297-302

Apriani, A., Oda, O. (2014). "Prosedur Pemesanan Dan Penerimaan Bahan Pastry Untuk Kegiatan Produksi Di Hotel Hilton Bandung”. LPPM Universitas Bina Sarana Informatika. DOI: https://doi.org/10.31311/par.v1i2.162.

Arikunto, S. (2006). "Prosedur Penelitian Suatu Pendekatan Praktek". Jakarta: PT. Rineka Cipta.

Arvanitoyannis, I., \& Mavropoulos, A. (2000). Implementation of the hazard analysis critical control point (HACCP) system to Kasseri/Kefalotiri and Anevato cheese production lines. Food Control, 11(1), 31-40.

Atia, M. A., Abdelgawad, A. M. (2017). Receiving and Storing Foods: The Procedures Followed in the Central Restaurants at University Dormitories Receiving and Storing Foods: The Procedures Followed in the Central Restaurants at University Dormitories. Minia Journal of Tourism and Hospitality Research Vol. 1, Issue 2.

Bungin, B. (2006). “Analisis Data Penelitian Kualitatif”. Jakarta: Raja Grafindo.

Bungin, B. (2007). "Penelitian Kualitatif: Komunikasi, Ekonomi, Kebijakan Publik dan Umum Sosial Lainnya". Jakarta: Putra Grafika. 
Cornelius, E. G. and Cronan, M. (1979), "Foodservice careers", Hazel Thompson Craig, New York.

Davis, B., Lockwood, A. and Stone, S. (1999), "Food and Beverage Management", the 3rd edition. Butterworth Heinemann. London.

Food Safety Programs-A guide to Standard3.2.1, (2007), "Food Safety Programs", Australian, New Zealand, Last accessed 8/2020. Retrieved from: http://www.foodstandards.gov.au/code/userguide/pages/foodsafetyprogra msag4567.aspx.

Foskett, D., Ceserani, v. and Kinton, R. (2003), "The Theory of Catering", 10th edition, Hodder\& Stoughton. London.

Gunawan, I. (2013). “Metode Penelitian Kualitatif: Teori dan Praktik”. Jakarta: PT. Bumi Aksara.

HACCP. (2017). How to Implement a Food Safety Plan. Communication Resource Unit, Food and Environmental Hygiene Department at 123A Fa Yuen Street, Mongkok, Kowloon. Centre for Food Safety.

HKSAR. (2002). How to implement a food safety plan. Risk communication Section, Food and Environmental Hygiene Department.

Hoof, H. B. McDonald, M. E., Yu, L. and Vallen, G. K. (1996), "A host of Opportunities: An Introduction to Hospitality Management", Irwin, New York.

Koto, E. S. (2012). Panduan Lengkap Sistem Manajemen Keamanan Pangan FSSC 22000 / ISO 2000. Jakarta (ID): REI.

Lagerkvist, C. J., Amuakwa-Mensah, F., and Tei Mensah, J. (2018). How consumer confidence in food safety practices along the food supply chain determines food handling practices: evidence from Ghana. Food Control, vol. 93, pp. 265-273.

Lao, S. I., et al. (2012). A real-time food safety management system for receiving operations in distribution centers. Expert Systems with Applications 39 (2012) 2532-2548. Elsevier Ltd. All rights reserved.

Leo, S. (2013). Kiat Jitu Menulis Skripsi, Tesis, Dan Disertasi. Jakarta: Erlangga.

Marsum, A.W. (2005). Restoran dan Segala Permasalahannya. Edisi Empat. Yogyakarta: Andi.

Marwaha, K. (2007). Food Hygine. Ansari Road: Daya Publishing House. GeneTech Books.

Moleong, L, J. (2005). "Metodologi Penelitian Kualitatif". Bandung: Remaja Rosdakarya. 
Muhdajir, N. (1996). “Metodologi Penelitian Kualitatif”. Edisi ketiga. Yogyakarta: Rake Sarasin.

Mulyana, D. (2007). "Ilmu Komunikasi: Suatu Pengantar". Bandung: Remaja Resdakarya.

Nasution, S. (1988). "Metode Penelitian Naturalistik-Kualitatif”. Bandung: Tarsiti.

Ninemeier, J. D. and Perdue, J. (2005), "Hospitality Operations: Careers in the Word's Greatest Industry", Pearson Education, Inc. Australia.

Nowicki, P., Dziadkowiec, J. (2016). "Implementation Of Food Safety Management System -Where It Brings The Real Value: A Case Study From Polish Enterprises". Proceedings of the 10th International Conference "Quality, Management, Environment, Education, Engineering" (ICQME 2016); Podgorica (Montenegro): Center for Quality, Faculty of Mechanical Engineering, University of Montenegro 2016. - 349 pp. ISBN 978-9940-527-49-5.

NSW Food Authority, (2011), "Food Safety Guidelines on Applying the 4-Hour/2Hour Rule for Temperature Control”, Last Accessed 8/2020. Retrieved from: http://www.foodauthority.nsw.gov.au.

Puckett, R. P. and Ninemeier, J. D. (1993), "Managing Foodservice Operations", the 3 rd edition. Dietary Managers Association. U.S.A.

Purnomo, H. (2006). Food Safety in Hospitality Industry. Jurusan Manajemen Perhotelan: Universitas Kristen Petra.

Suwithi, N. W. (2013). Industri Perhotelan. Kementrian Pendidikan dan Kebudayaan.

Raco, J. (2018). "Metode Penelitian Kualitatif: Jenis, Karakteristik dan Keunggulannya". Jakarta: PT. Gramedia Widiasarana.

Rahayu, W.P. (2011). Keamanan Pangan: peduli kita bersama. Jakarta: IPB Press.

Riduwan, A. (2011). "Rumus dan Data Dalam Aplikasi Stastitika". Bandung: Alfabeta.

Robinson, J, G. (2012), "Food Storage Guide: Answers the Question, How long Can I store Before its Quality Deteriorates or It's No Longer Safe to Eat?", last Accessed 8/2020. Retrieved from: https://www.ag.ndsu.edu/burleighcountyextension/pdfs/fcs/fcspublication s/fn-579-food-storage-guide.

Shiring, S., Jardine, R., and Mills, R. (2001), "Introduction to Catering -Ingredients for Success “, Thomson Learning, Inc., U.S.A.

Siswanto, B. (2011). "Manajemen Tenaga Kerja Indonesia Pendekatan Administratif dan Operasional”. Jakarta: Bumi Aksara. 
Sudarwan, D. (2002). “Menjadi Peneliti Kualitatif”. Bandung: Pustaka Setia.

Sugiyono. (2006). "Metode Penelitian Kuantitatif dan Kualitatif". Bandung: Alfabeta.

Sugiyono. (2008). “Metode Penelitian Kuantitatif Kualitatif dan RND”. Bandung: Alfabeta.

Texeira, S., Sampaio, P. (2011). Food safety management system implementation and certification: survey result. Industrial Engineering Research Conference.

Unnevehr, L. J., \& Jensen, H. H. (1999). The economic implications of using HACCP as a food safety regulation standard. Food Policy, 24, 625-635. 